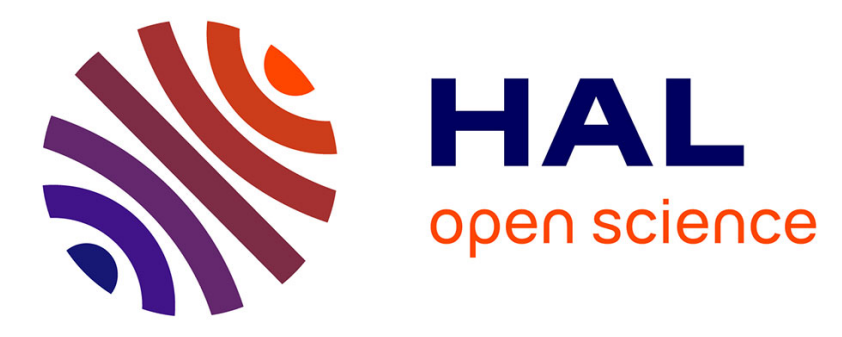

\title{
Work-Related Outcomes in Self-Employed Cancer Survivors: A European Multi-country Study
}

Steffen Torp, Alain Paraponaris, Elke van Hoof, Marja-Liisa Lindbohm, Sietske Tamminga, Caroline Alleaume, Nick van Campenhout, Linda Sharp, Angela de Boer

\section{To cite this version:}

Steffen Torp, Alain Paraponaris, Elke van Hoof, Marja-Liisa Lindbohm, Sietske Tamminga, et al.. Work-Related Outcomes in Self-Employed Cancer Survivors: A European Multi-country Study. Journal of Occupational Rehabilitation, 2019, 29 (2), pp.361-374. 10.1007/s10926-018-9792-8 . hal01989959

\section{HAL Id: hal-01989959 \\ https://hal-amu.archives-ouvertes.fr/hal-01989959}

Submitted on 14 May 2020

HAL is a multi-disciplinary open access archive for the deposit and dissemination of scientific research documents, whether they are published or not. The documents may come from teaching and research institutions in France or abroad, or from public or private research centers.
L'archive ouverte pluridisciplinaire HAL, est destinée au dépôt et à la diffusion de documents scientifiques de niveau recherche, publiés ou non, émanant des établissements d'enseignement et de recherche français ou étrangers, des laboratoires publics ou privés. 


\section{Work-related outcomes in self-employed cancer survivors: a European multi-country study}

Steffen Torp, PhD, Professor of Health Promotion; University College of Southeast Norway, Norway; email: steffen.torp@,usn.no

Alain Paraponaris, PhD, Professor of Economics, Aix-Marseille Univ, CNRS, EHESS, Centrale Marseille, AMSE, Marseille, France \& ORS PACA, Southeastern Health Regional Observatory, Marseille, France and Observatoire Régional de la Santé Provence-Alpes-Côte d'Azur; e-mail: alain.paraponaris@univ-amu.fr

Elke Van Hoof, PhD, Professor in Health \& Medical Psychology; Faculty of Psychology and Education Sciences, Vrije Universiteit Brussel, Belgium; email: elke.van.hoof@vub.ac.be

Marja-Liisa Lindbohm, PhD, Senior Researcher; Finnish Institute of Occupational Health, Helsinki, Finland and Adjunct Professor; University of Tampere, Tampere, Finland; email: marjaliisa.lindbohm@ttl.fi

Sietske J. Tamminga, PhD, Assistant Professor, Coronel Institute of Occupational Health, Amsterdam Public Health research institute, Academic Medical Center, the Netherlands; email: s.j.tamminga@amc.nl

Caroline Alleaume, MD, $\mathrm{PhD}$ candidate in public health-sociology, Aix-Marseille University, INSERM, IRD, SESSTIM, Sciences Economiques \& Sociales de la Santé \& Traitement de l’Information Médicale, Marseille, France; e-mail: caroline.alleaume@inserm.fr

Nick Van Campenhout, MSc, Psychologist, KLEP, Faculty of Psychology and Educational Sciences, Vrije Universiteit Brussel, Belgium; email: nick.van.campenhout@vub.be

Linda Sharp*, PhD, Professor of Cancer Epidemiology; Institute of Health \& Society, Newcastle University, Newcastle-upon-Tyne, UK; email: linda.sharp@ncl.ac.uk

Angela GEM de Boer*, PhD, Associate Professor of Occupational Health; Coronel Institute of Occupational Health, Amsterdam Public Health Research Institute, Academic Medical Center, the Netherlands; email: a.g.deboer@amc.uva.nl

*Sharp and de Boer contributed equally to this paper.

Corresponding author: Steffen Torp, $\mathrm{PhD}$, University College of Southeast Norway, Norway; email: steffen.torp@usn.no; tel: +4795933134

Running title: Cancer \& self-employment 


\begin{abstract}
Purpose: To describe patterns of self-employment and social welfare provisions for selfemployed and salaried workers in several European countries; to describe work-related outcomes after cancer in self-employed people and to compare these outcomes with the workrelated outcomes of salaried survivors within each sample; and to describe work-related outcomes for self-employed cancer survivors across countries.

Methods: Data from 11 samples from seven European countries were included. All samples had cross-sectional survey data on work outcomes in self-employed and salaried cancer survivors who were working at time of diagnosis $(n=22-261$ self-employed/101-1871 salaried). The samples included different cancers and assessed different outcomes at different times post-diagnosis.

Results: Fewer self-employed cancer survivors took time off work due to cancer compared to salaried survivors. More self-employed than salaried survivors worked post-diagnosis in almost all countries. Among those working at the time of survey, self-employed survivors had made a larger reduction in working hours compared to pre-diagnosis, but they still worked more hours per week post-diagnosis than salaried survivors. The self-employed had received less financial compensation when absent from work post-cancer, and more self-employed, than salaried, survivors reported a negative financial change due to the cancer. There were differences between self-employed and salaried survivors in physical job demands, work ability and quality-of-life but the direction and magnitude of the differences differed across countries.

Conclusion: Despite sample differences, self-employed survivors more often continued working during treatment and had in general worse financial outcomes than salaried cancer survivors. Other work-related outcomes differed in different directions across the countries.
\end{abstract}

Key words: Self-employment; Cancer survivor; Return to work; Rehabilitation; Social security; Quality of life 


\section{Introduction}

Self-employed people make up a large proportion of the workforce in Europe, and they contribute significantly to national and European GDP and economic vitality [1]. In Europe, the self-employed now comprise on average $15 \%$ of workers [2]. Around two-thirds of selfemployed people do not have employees (own-account workers) although this percentage differs substantially between countries [2]. The remainder have employees, indicating their wider economic and societal importance.

Perceived advantages of self-employment include freedom and decision-making autonomy and high job satisfaction [3, 4]. It has also been shown that self-employed people report better mental and physical health than salaried workers [5]. Park et al. [6] reported, for instance, that those who gained self-employment were 3.2 times more likely to report good mental health than those who stayed unemployed, a much greater effect than seen among those who became salaried workers (1.6 times).

However, self-employment can also be challenging because it is dominated by low paid and low skilled work, with long and irregular working hours [7]. The self-employed are largely outside the scope of the union or other directives on health and safety at work and, in some countries, they are not covered by the legislation on occupational safety and health [8]. Furthermore, they most prevalently work in certain 'high-risk' sectors, such as agriculture, fishing, construction and transport. With respect to work-related illness, Eurofound's fourth European working conditions survey (EWCS) indicated that self-employed workers consider themselves to be at greater risk for work-related injuries and diseases than salaried workers, with $46 \%$ of the self-employed reporting that work affects their health, compared with $33 \%$ of employees [7].

The number of cancer survivors of working age has been increasing rapidly in recent decades [9]. There is clear evidence that a cancer diagnosis can adversely affect a range of labour market and other work-related outcomes [10]. This has stimulated the development, across Europe, of interventions to support improved work outcomes in people with cancer [9, 11]. Most previous studies of work outcome post-cancer have focussed on salaried workers. Post-cancer work experiences of self-employed and salaried workers may differ due to differences in protections available (e.g. through social welfare system), motivation to work, quality of working life, and other factors between the two groups [12]. There are some suggestions from the literature that self-employed cancer survivors may be vulnerable to poorer 
work-related outcomes and/or worse health outcomes due to work-related decisions than salaried survivors, but the evidence is currently limited [12-15].

There has been a call to fill the knowledge gaps regarding the work-related outcomes of self-employed cancer survivors [16]. To help do this, we need research data on selfemployed persons. One potentially informative approach would be to identify existing datasets containing self-employed and salaried survivors and use these to explore similarities and differences in the same work-related outcomes across countries. Furthermore, such a multicountry study would facilitate the interpretation of the findings in the light of legislation and social security systems.

The aim of this study is therefore, for the first time, to use data from multiple European countries to: 1) describe patterns of self-employment and social welfare provisions for selfemployed and salaried workers in several European countries; 2) describe work-related outcomes after cancer in self-employed people; 3) compare these outcomes for the selfemployed with those for salaried workers within each sample; and 4) describe work-related outcomes after cancer for self-employed people across countries.

\section{Methods}

\section{Datasets}

We contacted members of the EU COST Cancer and Work Network (CANWON), which includes researchers, health professionals and occupational health practitioners from 23 European countries [17] to identify datasets for inclusion in this first study. Datasets were eligible if they were from quantitative studies of cancer survivors in Europe that included information on one or more work-related outcomes and distinguished between survivors who were self-employed and those who were salaried. Studies that included people with any form of cancer, diagnosed in adulthood, were eligible, as were both cross-sectional and longitudinal studies. The work-related outcomes could have been collected by self-completed postal questionnaire, telephone interview or face-to-face interview, but data collection had to have been conducted in the same way in self-employed and salaried workers. Information on employment status (i.e. self-employed or salaried) had to be available either for the time of diagnosis or at the time at which the work-related outcomes were assessed. To include as many datasets from as many countries as possible, datasets from which some results had previously been published were eligible and no restriction was placed on study size. Network members 
were asked to provide details of potentially eligible datasets that they were aware of and to which they had access. By this process, eleven datasets (studies) were identified from seven European countries (Belgium, Finland, France, Ireland, Netherlands, Norway and the UK).

\section{Methods and outcomes}

The methods used to identify and recruit the subjects included in each of the datasets are reported in detail elsewhere $[18,19,10,20-25]$. Briefly, the studies in Ireland, Norway, and the UK identified and recruited potentially eligible cancer survivors via population-based cancer registries; the study in France recruited survivors registered with the three sickness funds; the study in Finland recruited from a register in an oncology department; and the study in Belgium recruited from multiple hospital clinics. The two studies in the Netherlands recruited via hospital clinics and patient organisations. All of the studies had appropriate ethical approval and participants provided written informed consent before participation.

The studies collected information on a range of different work-related outcomes, used different instruments and collected outcome data at different times after diagnosis. From the study questionnaires, the authors of this paper identified all work-related outcomes that were potentially relevant to self-employed people. For the purposes of reporting, we have classified these into two groups: (i) outcomes relating to the evolution (or trajectory) of working life after diagnosis in survivors who were working at the time of diagnosis (e.g. whether working, retired, pensioned at time of survey or designated follow-up time point); and (ii) experiences of work and working life post-cancer in survivors who were working at the time of survey or designated follow-up time point. In all studies employment status was self-defined (i.e. study participants indicated whether they considered themselves self-employed or a salaried worker).

\section{Contextual information}

To set the findings for cancer survivors in context, for each of the seven countries from which eligible datasets had been identified, we documented the patterns of self-employment in the population and social welfare provisions for self-employed and salaried workers across countries (Table 1 and 2). Data on patterns of self-employment was obtained from routine labour market surveys reported by national statistics organisations [26-36] and Eurostat [2]. Information from 2016 (or the closest available year) was abstracted on numbers of selfemployed and salaried workers, on the distribution of self-employed across sectors, and on average hours worked, earnings and gender. 


\section{Analysis}

The primary aim of the analysis was to compare each outcome between salaried and selfemployed survivors (i.e. within sample comparisons, rather than between-sample or betweencountry comparisons). In the analysis of the outcomes related to the trajectory of working life post-cancer, survivors were categorised as self-employed or salaried based on employment status at the time of diagnosis. For the outcomes relating to work experiences post-cancer, employment status was based on that recorded at the time of survey; in the event that this information was not available, survivors were categorised according to their status at the time of diagnosis. We used descriptive statistics to summarize the work-related outcomes and compared these between salaried and self-employed survivors using appropriate tests (e.g. ttests, with adjustment for unequal variances where necessary). $\mathrm{P}<0.05$ (on a two-sided test) was considered statistically significant. In the text, we comment primarily on findings for which the $p$ value for the comparison of self-employed vs salaried was $<0.1$.

\section{Results}

\section{Contextual information}

Table 1 presents information regarding self-employment in the countries in which the different surveys were performed. The percentage of self-employed in the participating countries' labour forces range from 7\% (Norway) to $17 \%$ (Ireland and the Netherlands). In all countries, approximately one fifth of the self-employed work in industry. Likewise, about one fifth work in primary professions except for the UK and Netherlands where only $6 \%$ of self-employed work in this sector. In these two countries, the proportion of self-employed working in the service sector is thus higher than in the other countries.

In all countries, the self-employed in general work more hours per week $(35.9-51.4)$ compared to salaried workers $(29.0$ - 36.6) (Table 1). In Belgium, the difference between selfemployed and salaried workers is 16 hours per week on average while in France and Ireland it is about 10 hours. The yearly income among self-employed is lower compared to salaried workers in four countries (and particularly in the UK and Belgium), and higher in three. There are more male than female self-employed (between $64 \%$ and $77 \%$ are men) in all countries.

Insert Table 1 about here 
Except for modest co-payments, cancer patients do not have to pay for cancer treatments in any of the participating countries, and access to treatment is not depended on any aspect of employment status (Table 2). The systems for social welfare provisions (e.g. sick pay and disability pension) when getting cancer (or any other disease) differ between countries. In the Netherlands, Ireland and UK most, or all, self-employed workers are not entitled to statutory payments when getting an illness. In Belgium, Finland and Norway, both self-employed and salaried workers receive provisions from the public welfare system when ill, but the percentage of the replacement provision is somewhat lower for most self-employed people compared to salaried workers. In France, for self-employed workers, the financial compensation for sick leave available within the public welfare system depends on occupation: farmers, shopkeepers, craft persons receive the same compensation as salaried workers, whereas liberal professions such as architects, lawyers, physicians and pharmacists receive compensation only if they have subscribed for a private insurance.

Insert Table 2 about here

\section{Trajectory of work after cancer}

All of the eleven eligible studies were cross-sectional (Table 3). Some studies included only one cancer diagnosis whereas others included a range of cancer diagnoses. The participants had been diagnosed with cancer in the period from 1997 to 2016 and the surveys were performed three weeks to 6 years after diagnosis. Across studies, the number of self-employed cancer survivors varied between 22 and 261 whereas the number of salaried survivors varied between 101 and 1871 .

Insert Table 3 about here 
In Table 4, results are shown from Belgium, Finland, France, Ireland, Norway and the UK on work status, occupational change, sick leave and financial issues at time of survey for those cancer survivors who were self-employed or salaried workers at time of diagnosis (these outcomes were not considered in the two studies in the Netherlands). More self-employed than salaried survivors worked at survey in all countries, with the exception of Norway, and the differences were particularly evident in Belgium and Ireland. In France, more salaried than self-employed survivors were pensioned at survey while the opposite was true in Norway. In Finland, France and Norway, more self-employed than salaried cancer survivors had made occupational changes, but the difference between the groups was statistically significant in the Norwegian study only. The Finnish and Norwegian studies asked whether the changes were due to the cancer: in both countries, among those having made occupational changes, more self-employed than salaried survivors reported that the changes were due to cancer but the differences did not reach statistical significance $(40 \%$ vs $13 \%, p=0.16$ in Finland and $72 \%$ vs $65 \%, p=0.32$ in Norway).

Compared to salaried survivors, fewer self-employed survivors had taken time off work due to cancer in France, the UK and one of the Irish studies (Ir1) while in the other studies there were no significant differences (Table 4). As regards duration of time off work due to cancer, the self-employed survivors in the French study reported longer periods away from work compared to salaried survivors, whereas in two of the Irish studies (Ir2 and Ir3) the duration of time off work was shorter than among salaried survivors.

In Ireland and the UK, far fewer self-employed than salaried cancer survivors had received some kind of financial compensation for time off work, while there was no significant difference regarding financial compensation between self-employed and salaried survivors in France. In the French and Norwegian studies, significantly more self-employed than salaried cancer survivors reported a negative financial change due to cancer, and in one of the Irish studies (Ir1) 10\% more of the self-employed reported that finances influenced their return to work, but this was not statistically significant.

Insert Table 4 about here

Table 5 presents results for working hours among self-employed and salaried cancer survivors working at survey, from 10 studies (six countries) where relevant data was available. In all 
studies, except the Belgian one (which had a short follow-up time), more self-employed than salaried survivors had reduced their working hours from time of diagnosis [significant for France, Norway and in one of the Irish studies (Ir4)] and the self-employed had reduced their working hours more than the salaried [significant for France and two of the Irish studies (Ir1, Ir2)]. Despite this greater reduction in working hours, self-employed survivors in all countries worked more hours per week than salaried survivors [significant for two of the Irish studies $(\operatorname{Ir} 1, \operatorname{Ir} 2)]$.

Insert Table 5 about here

\section{Experiences of work after cancer}

Table 6 shows results for job demands, work ability and quality of life among self-employed and salaried cancer survivors working at survey, from nine studies (six countries) with relevant data. In the French study, there were more self-employed than salaried cancer survivors who regarded their job as physically demanding whereas the opposite was true in one of the Dutch studies (Ne2). There were no differences between how self-employed and salaried regarded the mental demands at work in any of the three studies that measured job demands.

As regard subjective work ability, self-employed survivors in Norway reported significantly lower scores (poorer work ability) than salaried survivors, but such a difference was not evident among cancer survivors in Finland.

The Dutch (Ne1, work-related quality of life), French (physical and mental health related quality of life) and UK (general health-related quality of life) studies reported higher quality of life among self-employed compared to salaried survivors. In contrast, in the Finnish (mental health related quality of life) and one of the Irish ( Ir4, general health-related quality of life) studies, the self-employed reported poorer quality of life compared to salaried survivors. The Norwegian and two other Irish (Ir1 and Ir2) studies did not show any difference in quality of life among self-employed and salaried cancer survivors.

Insert Table 6 about here 


\section{Discussion}

The results of this European multi-country study indicate that fewer self-employed cancer survivors take time off work due to cancer compared to salaried survivors. After treatment, self-employed survivors often work more hours than salaried survivors even after having made greater reductions in working hours. In most countries, self-employed survivors receive less financial compensation and more often report negative financial changes due to cancer. There are differences in the quality of life, work ability and job demands between the two groups, but the direction and magnitude vary. Overall, the included studies indicate that self-employed and salaried cancer survivors differ when it comes to labour market and other work-related outcomes, but the patterns do vary between countries.

\section{Self-employment, health and job satisfaction}

In general, as shown in our contextual data, self-employed people work more hours per week than salaried workers [2]. Our results indicate that this difference is maintained when getting cancer and that the occurrence of sick leave is lower among the self-employed. A Canadian study [37] has shown similar results as shown in most of the European samples presented in our study with self-employed survivors more often working during cancer treatment, taking sick leave later and taking less sick leave than salaried survivors. Also consistent with our results on financial constraints among the self-employed, the Canadian project documented that self-employed cancer survivors more often than salaried survivors report wage loss during and after cancer treatment [39]. In an Irish study on the financial impact of cancer, Sharp and Timmons [20] interviewed oncology-based social workers who had extensive experience with supporting and guiding both self-employed and salaried cancer survivors in financial matters. These social workers stated that, in their view, self-employed cancer survivors are financially a particularly vulnerable group [20].

Although in comparison with salaried workers, the self-employed generally work more hours per week, they report better health and higher job satisfaction $[5,40,6]$. One reason for this may be that they experience more freedom and autonomy at work [41, 42]. Our results on work ability and quality of life among cancer survivors do not fully confirm these observations: we found no clear pattern of better work ability or quality of life among the self-employed survivors. It has been shown that uncertainty about income, particularly in case of medical problems, is a common stressor among self-employed [44]. A study on cancer survivors in 
Norway [14] suggests that a difficult cancer-related financial situation mediates a negative effect of self-employment on work ability. The conflicting results on work ability and quality of life in the current study may result from differences between countries in the work and financial situation of self-employed, either because different professions constitute the countries' main groups of self-employed and/or because social security systems and provisions are different. Differences in the cancer sites, ages and gender of study participants may also contribute.

\section{Balancing business and health needs}

Although they constitute a heterogeneous group, self-employed people share a common trait: the absence of a subordination tie towards any hierarchy or employer [45, 41]. In this regard, they must face a twofold uncertainty concerning both their health and their business [13]. As a result, when becoming ill, they must internalise a trade-off between the health of their business, as an employer, and their own health, as a worker. Our findings on long working hours and shorter sick leave among self-employed survivors suggest that the conclusion of this deliberation seems to favour unambiguously the business interests [46, 47]. This is likely because mortgages and corporate tax have to be paid, whatever the business cycle of the individual firm or the health of the owner $[48,49]$ and because loss of customers during long cancer treatment and sick leave may result in bankruptcy of the business [13].

The discrepancies in health insurance and social welfare arrangements (or the lack of such arrangements for the self-employed) probably exacerbate differences in how selfemployed and salaried workers respond to a cancer diagnosis. In that respect, where the financial compensation for sickness among the self-employed sickness is poorer (Ireland), the length of sick leave due to cancer is among the shortest. Where the insurance arrangements are the most protective (France and Norway) and less discriminatory against the self-employed compared to salaried workers (in Norway, for all the self-employed and in France, for the selfemployed who are not practising liberal professions), the length of sick leave due to cancer is the longest.

These findings firstly question the initiative of running one's own business [51]. In Belgium, Ireland, the Netherlands and the UK, where incomes are lower for self-employed than for salaried workers (unlike Norway, Finland and France), the higher economic risks entailed by self-employment are obviously not rewarded by higher earnings. In these countries, self-employment may be viewed, to some extent, as the opportunity to avoid unemployment and the self-employed are, then, at higher risk of health deprivation and economic insecurity. 
In Norway and France, risk taking seems to be less constrained by the situation in the labour market and self-employment might constitute a positive choice of entrepreneurship.

Secondly, the findings advocate for greater attention to be paid to the non-financial assistance that self-employed may require in their work. For instance, in a French study [52], there was no difference in the occurrence of sick leave between self-employed people who had at least a relative or an associate involved in their business and those with a one-person business, whereas sick leave was twice as high among self-employed people (with or without colleagues) who could be replaced by a relative or an associate compared to self-employed who did not have this opportunity.

Finally, the contrasting behaviours of cancer survivors when facing employment issues may be fuelled by changes in individual preferences regarding priorities in life at large [53] and in working life in particular $[54,55]$, which seem unlikely to be the same for self-employed and salaried workers.

\section{Strengths and limitations}

This is the first study to compare work outcomes of self-employed and salaried cancer survivors in multiple countries. Our intention in bringing together these datasets was not to conduct the definitive study of working life among self-employed people with cancer, but to begin to shed a light on an under researched group who may be vulnerable to poor work-related outcomes. Although some of the studies have small numbers of self-employed participants, limiting statistical power for comparisons, and analysis were unadjusted, the paucity of data regarding the impact of cancer on working life among this group justifies their inclusion. In terms of other limitations, all of the results are conditional on the willingness of the surveyed survivors to respond. We do not have information on eligible non-respondents and therefore, cannot assess the extent to which results may be influenced by participation bias. We also lacked detailed information on the nature and content of the jobs held/work done by survivors, either salaried or self-employed, at the time of diagnosis; this has implications for the interpretation of differences between countries and between studies within one country. In addition, some of the studies were conducted several years ago and policy and economic circumstances may have changed; this highlights the need for up-to-date studies of this topic. It should also be noted that the studies themselves were not designed to study self-employed individuals. 
While we identified relevant datasets through a European network, it is possible that there are other datasets which also distinguish between self-employed and salaried cancer survivors; we, therefore, hope that this work will stimulate further investigation and research on this topic in these existing - or, indeed, in new - datasets both in Europe and beyond. The studies included were not designed a priori for comparison and this, and data protection legislation, ethical approvals, and the consent obtained from participants, precluded pooling of individual-level data. The heterogeneity in study methods and, in particular, in the time post-diagnosis at which outcomes were assessed (which ranged from 3 weeks to 6 years) meant that we considered meta-analysis inappropriate. Nonetheless, we carefully scrutinized the study questionnaires in a post hoc effort to identify outcomes that were reasonably comparable across studies. However, not all of the questions/tools used to assess outcomes had been previously validated in the setting in which they were applied. Finally, all of the studies had a cross-sectional design, which is an important limitation.

\section{Implications for research}

The evidence-base on self-employed cancer survivors is limited; few studies report any data on self-employed survivors, and they are usually not the research focus [16]. Self-employed cancer survivors are furthermore a heterogeneous group with different characteristics with respect to education, occupation, socio-economic status, and type of self-employment. More research (ideally population-based and with a longitudinal design) is needed to assess the effects of these characteristics on work-related outcomes among self-employed cancer survivors. The work-related outcomes of different groups of self-employed cancer survivors may also differ; this has not been investigated to date.

Variations in social welfare systems between countries imply that findings on workrelated outcomes of self-employed people in one country are unlikely to be entirely transferrable to another country. Studies on the impact of social welfare systems on workrelated outcomes of self-employed cancer survivors should therefore be initiated. These differences in social welfare systems could also affect the implementation of interventions to support return-to-work after cancer. Moreover, data is lacking in many countries on: the impact of cancer on subjective work-related outcomes of self-employed people; the effect on their companies and people who are working for them; prognostic factors for work-related outcomes of self-employed cancer survivors; and the self-employed decision-making, subjective needs and potential changes in work-related preferences around work after cancer. As we have noted previously, there is an urgent need for research in all of these areas [16]. 
Complete identification of self-employed cancer survivors could potentially be achieved by registry-based data linkage studies (at least in countries where linkage of relevant datasets is permitted and possible). Nevertheless, registry data have limitations, including lack of information on sick leave or sickness absence for non-salaried workers, and on many key work-related outcomes (e.g. work ability, quality of working life). Furthermore, they cannot supply any information on the work-related experiences of self-employed cancer survivors. This implies that research involving primary data collection among self-employed survivors, using both quantitative and qualitative methods, is also required.

\section{Implications for practice}

Our results indicate that, compared to salaried cancer survivors, self-employed survivors work more often and more hours per week during and after treatment. Although this may, in part, be due to the over-representation of men among the self-employed and gender differences in working hours and earnings, it is also likely to be because, for the self-employed, securing their business and income takes priority over recovering from cancer and its treatment. This suggest that self-employed cancer survivors may need support to find the right balance between maintaining business and taking care of their health. Nevertheless, most interventions to enhance cancer survivors' work-related outcomes have been relevant for salaried workers only. These interventions have been targeted at return to work after treatment [9] and not at working through treatment that might be more relevant for the self-employed. Furthermore, existing interventions typically involve supervisors, colleagues and occupational physicians who might not be available to the self-employed. To understand what interventions would effectively support self-employed survivors, and how these can be implemented in policy and practice, involvement of researchers, health professionals, service providers, policy-makers and the selfemployed is required. If this can be accomplished, the work-related and health outcomes of self-employed survivors can be improved. Finally, this will not only generate benefits for the self-employed cancer survivors but also for their families and their employees, the economy and the society at large.

\section{Conclusion}

This study is the first to use data from multiple countries on work-outcomes among selfemployed cancer survivors. It indicates that, compared to salaried survivors, the self-employed more often continue working after cancer and work longer hours. The difference in the length 
of sick leave among self-employed and salaried survivors, however, varies across countries. Some of the worse outcomes among the self-employed cancer survivors seem to be related to less protective social security system for the self-employed. Self-employed workers should be encouraged to have appropriate insurance where available. Nevertheless, our study shows that the income of self-employed people is lowest in the countries in which the financial support is poorest when being sick, which indicates that many self-employed could not afford buying such expensive insurances anyhow. Further, the gap in consequences of cancer between selfemployed and salaried is not wiped out in countries in which the social benefits are rather equally distributed. Research is needed to identify prognostic factors for work-related outcomes in self-employed cancer survivors and to assess the impact of social security systems on these. Interventions that help self-employed survivors to balance recovery after cancer with securing their business should be developed.

\section{Acknowledgements}

We are grateful to the following persons for their work on the different national studies:

Dr Tyna Taskila (Finland); Patrick Peretti-Wattel, Marc-Karim Bendiane, Claire Chauvet and the VICAN study group (France); Dr Frances Drummond, Mr Alan O'Ceilleachair and Dr Aileen Timmons (Ireland); Dr Merel de Jong (Netherlands); Dr Tone Fløtten and Ms Federica Previtali (Norway); and Dr Anna Gavin and Dr Heather Kinnear (UK).

The included studies were funded by: KOm op tegen Kanker, Flemish Cancer League (Belgium); Nordic Cancer Union, Finnish Work Environment Fund, and Finnish Cancer Organisations (Finland); National Cancer Institute (Institut National du Cancer, France); Health Research Board, Irish Cancer Society, and Prostate Cancer UK (Ireland and UK); Dutch Cancer Society (Netherlands); Norwegian Cancer Society (Norway)

\section{Compliance with ethical standards}

\section{Conflicts of interest:}

This paper was supported by EU COST Action Cancer and Work Network (CANWON) IS1211. No conflicts of interest declared.

Research involving human participants and/or animals:

All procedures performed in studies involving human participants were in accordance with the ethical standards of the institutional and/or national research committee and with the 1964 Helsinki declaration and its later amendments or comparable ethical standards.

\section{Informed consent:}

All participants provided written informed consent before participation. 


\section{References}

1. Koellinger PD, Thurik AR. Entrepreneurship and the business cycle. Rev Econ Stat. 2012; doi:10.2139/ssrn. 1403867.

2. Eurostat. Labour market and labour force survey. 2015. http://ec.europa.eu/eurostat/statistics-

explained/index.php/Labour_market_and_Labour_force_survey_(LFS)_statistics. Accessed 20 Feb 2017.

3. Starr KT. "I want to be my own boss": Self-employment and legal business structures. Nursing (Lond). 2016; doi:10.1097/01.NURSE.0000482274.49165.d1.

4. Algava E, Cavalin C, Celèrièr S. The remarkably good health of self-employed. Travail et emploi. 2013; doi:10.4000/travailemploi.6296.

5. Stephan U, Roesler U. Health of entrepreneurs versus employees in a national representative sample. J Occup Organ Psychol. 2010; doi:10.1348/096317909X472067.

6. Park S, Chan KCG, Williams EC. Gain of employment and perceived health status among previously unemployed persons: evidence from a longitudinal study in the United States. Public Health. 2016; doi:10.1016/j.puhe.2015.11.008.

7. Cockburn W, Treutlein D, Karjalainen A, Kaluza S, Papale A, Verjans M. A review of methods used across Europe to estimate work-related accidents and illnesses among the self-employed. European Agency for Safety and Health at Work; 2010.

8. Arbeids-og inkluderingsdepartementet. Lov om arbeidsmiljø, arbeidstid og stillingsvern mv. (arbeidsmiljøloven) [The Work Envionment Act]. Oslo: Ministry of Labour and Social Inclusion; 2005.

9. de Boer A, Taskila TK, Tamminga SJ, Feuerstein M, Frings-Dresen M, Verbeek JH. Interventions to enhance return-to-work for cancer patients. Cochrane Database Syst Rev 2015; doi:10.1002/14651858.CD007569.pub3.

10. Pearce A, Timmons A, O’Sullivan E, Gallagher P, Gooberman-Hill R, Thomas A et al. Long-term workforce participation patterns following head and neck cancer. J Cancer Surviv. 2015; doi:10.1007/s11764-014-0382-2.

11. Désiron H, Crutzen R, Godderis L, Hoof E, de Rijk A. Bridging health care and the workplace: Formulation of a return-to-work intervention for breast cancer patients using an intervention mapping approach. J Occup Rehabil. 2016; doi:10.1007/s10926-015-96203. 
12. Tison A. Decisions on the labor market in a context of both economic and health uncertainty. Empirical and theoretical approaches with applications for self-employed workers diagnosed with cancer. Marseille: Aix-Marseille University; 2016.

13. Sharp L, Timmons A. Social welfare and legal constraints associated with work among breast and prostate cancer survivors: experiences from Ireland. J Cancer Surviv. 2011; doi:10.1007/s11764-011-0183-9.

14. Ha-Vinh P, Régnard P, Huiart L, Sauze L, Eisinger F. Self-employed and small business owners diagnosed with cancer: effect on entrepreneurial survival. Santé publique (Vandoeuvre-lès-Nancy, France). 2015;27(1 Suppl):S145.

15. Torp S, Syse J, Paraponaris A, Gudbergsson S. Return to work among self-employed cancer survivors. J Cancer Surviv. 2017; doi:10.1007/s11764-016-0578-8.

16. Sharp L, Torp S, van Hoff E, de Boer A. Cancer and its impact on work among the selfemployed: a need to bridge the knowledge gap. Eur J Cancer Care (Engl). 2017; doi: 10.1111/ecc. 12746

17. de Boer A. The European Cancer and Work Network: CANWON. J Occup Rehabil. 2014; doi:10.1007/s10926-013-9474-5.

18. de Jong M. Quality of working life of cancer survivors: Development and evaluation of a measurement instrument: University of Amsterdam; 2016.

19. Pauwels EEJ, Charlier C, De Bourdeaudhuij I, Lechner L, Van Hoof E. Care needs after primary breast cancer treatment. Survivors' associated sociodemographic and medical characteristics. Psycho-Oncology. 2013; doi:10.1002/pon.2069.

20. Sharp L, Timmons A. The financial impact of a cancer diagnosis. Dublin: National Cancer Registry Ireland; 2010.

21. Taskila T, Martikainen R, Hietanen P, Lindbohm M-L. Comparative study of work ability between cancer surviors and their referents. Eur J Cancer. 2007;43:914-20.

22. Drummond F, Kinnear H, Donnelly C, O'Leary E, Burns R, O’Brien K et al. Challenges of establishing a population-based patient reported outcomes study (PROMs) using national cancer registries across two jurisdictions; The Prostate Cancer Treatment, your experience (PiCTure) Study. BMJ Open 2015;5 (4):e006851.

23. Hanly P, Walsh PM, A OC, Skally M, Staines A, Kapur K et al. Work-related productivity losses in an era of ageing populations: the case of colorectal cancer. J Occup Environ Med. 2013; doi:10.1097/JOM.0b013e3182820553.

24. Bouhnik AD, Bendiane MK, Cortaredona S, Sagaon Teyssier L, Rey D, Berenger C et al. The labour market, psychosocial outcomes and health conditions in cancer survivors: 
protocol for a nationwide longitudinal survey 2 and 5 years after cancer diagnosis (the VICAN survey). BMJ Open. 2015; doi:10.1136/bmjopen-2014-005971.

25. Torp S, Nielsen RA, Gudbergsson SB, Dahl AA. Worksite adjustments and work ability among employed cancer survivors. Support Care Cancer. 2011; doi:10.1007/s00520-0111325-3.

26. Sécurité Sociale Entrepreneurs Indépendants. Basic statistics and detail tables of selfemployed Brussels. 2016. https://rproxy.rsvz-inasti.fgov.be/WebSta/index_nl.htm. Accessed 8 Jun 2017.

27. Rijksinstituut voor ziekte- en invaliditeitsverzekering. Verklarende factoren met betrekking tot de stijging van het aantal invaliden. Werknemersregeling en regeling der zelfstandigen. Periode 2006 - 2015 [Descriptive factors concerning the increase of longterm absence. Salaried and selfemployed individuals. Period 2006 - 2015]. Brussels. 2015. http://www.inami.fgov.be/SiteCollectionDocuments/studie_verklarende_factoren_stijgin g_invaliden.pdf. Accessed 3 Jul 2017.

28. Statistics Finland. Official Statistics of Finland: Labour force survey. ISSN=1798-7857. Employment and unemployment 2016, Appendix table 11. Employees and self-employed persons aged 15-74 by industry (TOL 2008) in 2012 - 2016. Helsinki. 2016. http://www.stat.fi/til/tyti/2016/13/tyti_2016_13_2017-04-12_tau_011_en.html. Accessed 20 Jun 2017.

29. National Institute of Statistics and Economic Studies (INSEE). Une photographie du marché du travail en 2014 [A picture of the labor market in 2014]. 2015. https://www.insee.fr/fr/statistiques/1560271 Accessed 8 Jun 2017.

30. (INSEE) NIoSaES. Emploi salarié et non-salarié par activité en 2015 [Salaried and nonsalaried employment by occupation in 2015]. 2015. https://www.insee.fr/fr/statistiques/2424696. Accessed 8 Jun 2017.

31. Central Bureaus Statistics (CBS) The Netherlands. Arbeidsdeelname; kerncijfers. 2016. http://statline.cbs.nl/statweb/publication/?vw $=t \& d m=s \ln 1 \& p a=82309$ ned $\& d 1=0,2-$ $10,22 \& \mathrm{~d} 2=0 \& \mathrm{~d} 3=0 \& \mathrm{~d} 4=0 \& \mathrm{~d} 5=(1-13)-1 \& \mathrm{hd}=151216-1202 \& \mathrm{hdr}=\mathrm{g} 1, \mathrm{~g} 2, \mathrm{~g} 3, \mathrm{t} \& \mathrm{stb}=\mathrm{g} 4$. Accessed 13 March 2018

32. Central Bureaus Statistics (CBS) The Netherlands. Arbeidsvolume naar bedrijfstak en geslacht; nationale rekeningen. 2016. http://statline.cbs.nl/Statweb/publication/?DM=SLNL\&PA=82579NED\&D1=0\&D2=0\& $\mathrm{D} 3=\mathrm{a} \& \mathrm{D} 4=0-96 \& \mathrm{D} 5=0-14,1 \& \mathrm{HDR}=\mathrm{G} 1, \mathrm{G} 2, \mathrm{~T} \& \mathrm{STB}=\mathrm{G} 3, \mathrm{G} 4 \& \mathrm{VW}=\mathrm{T} . \quad$ Accessed 13 March 2018. 
33. Statistics Norway. Labour Force Survey. 2016. https://www.ssb.no/statistikkbanken/selecttable/hovedtabellHjem.asp?KortNavnWeb=ak u\&CMSSubjectArea=arbeid-og-lonn. Accessed 8 Jun 2017.

34. Office of National Statistics UK. Labour Force Survey, table EMP09. Q3 2016. https://www.ons.gov.uk/employmentandlabourmarket/peopleinwork/employmentandem ployeetypes/datasets/employeesandselfemployedbyoccupationemp09/current. Accessed 10 Aug 2017

35. Finland S. Official Statistics of Finland: Income distribution statistics. ISSN=1799-1331. 2017. http://www.stat.fi/til/tjt/tau en.html. Accessed 20 jun 2017.

36. Central Statistics Office Ireland. Quarterly National Household Survey, Q1-Q3 2016. http://www.cso.ie/en/statistics/labourmarket/. Accessed 10 Aug 2017.

37. Drolet M, Maunsell E, Mondor M, Brisson C, Brisson J, Masse B et al. Work absence after breast cancer diagnosis: a population-based study. Can Med Assoc J. 2005; doi:10.1503/cmaj.050178.

38.

39. Lauzier S, Maunsell E, Drolet M, Coyle D, Hebert-Croteau N, Brisson J et al. Wage losses in the year after breast cancer: extent and determinants among Canadian women. J Natl Cancer Inst. 2008; doi:10.1093/jnci/djn028.

40. Benz M, Frey S. Being independent is a great thing: Subjective evaluations of selfemployment and hierarchy. Economica. 2006; doi:10.1111/j.1468-03335.2007.00594.

41. Prottas DJ, Thompson CA, Tetrick LE. Stress, satisfaction, and the work-family interface: A comparison of self-employed business owners, independents, and organizational employees. J Occup Health Psychol. 2006; doi:10.1037/1076-8998.11.4.366.

42. Hatfield I. Self-employment in Europe. Institute for Public Policy Research; 2015.

43. Rietveld CA, Van Kippersluis H, Thurik AR. Self-employment and health: Barriers or benefits? Health Econ (Engl). 2015; doi:10.1002/hec.3087.

44. Schonfeld I, Mazzola J. A Qualitative Study of Stress in Individuals Self-Employed in Solo Businesses. J Occup Health Psychol. 2015; doi:10.1037/a0038804.

45. Hébert R, Link A. In search of the meaning of entrepreneurship. Small Bus Econ. 1989; doi:10.1007/BF00389915.

46. Egan S. The health tradeoffs of entrepreneurship. New York Time. 2013 8/08/2013.

47. Lewin-Epstein N, Yuchtman-Yaar E. Health risks of self-employment. Work Occup. 1991; doi:10.1177/0730888491018003003. 
48. Agarwal R, Gort M. The evolution of markets and entry, exit and survival of firms. Rev Econ Stat. 1996; doi:10.2307/2109796.

49. Agarwal R, Audretsch DB. Does entry size matter? The impact of the life cycle and technology on firm survival. J Ind Econ. 2001; doi:10.1111/1467-6451.00136.

50. Caliendo M, Fossen F, Kritikos A. Personality characteristics and the decisions to become and stay self-employed. Small Bus Econ. 2014; doi:10.1007/s11187-013-9514-8.

51. Gilbert B, Audretsch D, McDougall P. The emergence of entrepreneurship policy. Small Bus Econ. 2004; doi:10.1023/B:SBEJ.0000022235.10739.a8.

52. Ha-Vinh P, Régnard P, Sauze L. Self-employed workers with cancer - A threat to the survival of their businesses. Rev Fr Aff Soc. 2014;1(1-2):192-215.

53. Sahm CR. How much does risk tolerance change? Quart J of Fin. 2012; doi:10.1142/S2010139212500206.

54. Siegrist J, Quick JC. Adverse health effects of high-effort/low-reward conditions. J Occup Health Psychol. 1996; doi:10.1037/1076-8998.1.1.27.

55. Hamermesh DS. Expectations, life expectancy, and economic behavior. Q J Econ. 1985; doi:10.2307/1885388.

56. Toivanen S, Härter Griep R, Mellner C, Vinberg S, Eloranta S. Mortality differences between self-employed and paid employees: a 5-year follow-up study of the working population in Sweden. Occup Environ Med. 2016; doi:10.1136/oemed-2015-103472.

57. Eurostat. Average number of usual weekly hours of work in main job, by sex, professional $\begin{array}{lllll}\text { status, full-time/part-time } & \text { and }\end{array}$ http://appsso.eurostat.ec.europa.eu/nui/show.do?dataset=lfsa_ewhuis\&lang=eng. Accessed 4 Jul 2017.

58. Van Hoof E, Pauwels E, Charlier C, De Bourdeaudhuij I. Breast cancer survivors' physical and psychosocial profiles and their relationship to the need for information and support after primary medical treatment: A cluster-analytic approach. Psycho-Oncol. 2013;22:3434.

59. Hakanen JJ, Lindbohm ML. Work engagement among breast cancer survivors and the referents: the importance of optimism and social resources at work. J Cancer Surviv. 2008; doi:10.1007/s11764-008-0071-0.

60. Hanly P, Timmons A, Walsh PM, Sharp L. Breast and prostate cancer productivity costs: a comparison of the human capital approach and the friction cost approach. Value Health. 2012; doi:10.1016/j.jval.2011.12.012. 
Table 1: Description of self-employment in each participating country ${ }^{1}$

\begin{tabular}{|c|c|c|c|c|c|c|c|}
\hline & $\begin{array}{l}\text { Total } \\
\text { population }\end{array}$ & $\begin{array}{l}\text { Total } \\
\text { labour force }\end{array}$ & $\begin{array}{l}\text { SE in } \\
\text { labour force }\end{array}$ & SE (\%) by sector 2,3 & $\begin{array}{l}\text { Mean working } \\
\text { hours/week }^{4} \\
\text { (SE vs Sal) }^{2}\end{array}$ & $\begin{array}{l}\text { Mean earnings/year } \\
\text { (Euro) } \\
\text { (SE vs Sal) }^{2}\end{array}$ & $\begin{array}{l}\text { Male \% } \\
\text { (SE vs Sal) }\end{array}$ \\
\hline Belgium & 11.2 mill. & 4.7 mill. & $15 \%$ & $08-22-70$ & 51.4 vs 35.1 & 21,600 vs 47,500 & 68 vs 50 \\
\hline Finland & 5.5 mill. & 2.4 m26-36ill. & $14 \%$ & $19-21-60$ & 41.3 vs 36.2 & 34,300 vs $29,800^{4}$ & 68 vs 49 \\
\hline France & 66.9 mill. & 25.8 mill. & $11 \%$ & $15-17-68$ & 46.5 vs 36.0 & 29,100 vs 26,400 & 66 vs 50 \\
\hline Ireland & 4.7 mill. & 2.0 mill. & $17 \%$ & $25-21-54$ & 44.8 vs 34.6 & 25,700 vs 35,100 & 77 vs 50 \\
\hline Netherlands & 17.1 mill. & 8.5 mill. & $17 \%$ & $07-15-78$ & 35.9 vs 29.0 & 37,100 vs 41,300 & 64 vs 52 \\
\hline Norway & 5.2 mill. & 2.7 mill. & $7 \%$ & $15-18-67$ & 37.6 vs 33.5 & 67,000 vs 56,000 & 70 vs 51 \\
\hline UK & 61.1 mill. & 31.7 mill. & $15 \%$ & $05-24-72$ & 37.8 vs 36.6 & 12,700 vs $23,400^{5}$ & 66 vs 51 \\
\hline
\end{tabular}

${ }_{1}^{1}$ Information (2016 or the closest available year) retrieved from routine labour market surveys reported by Eurostat [2,57] and national statistics organisations [26 - 36].

${ }^{2} \mathrm{SE}=$ self-employed, Sal= salaried

${ }^{3}$ Primary - secondary - tertiary sectors

${ }^{4}$ Household's disposable cash income per consumption unit

${ }^{5}$ Median annual earnings 
Table 2: Description of social security provisions in each participating country

Belgium Self-employed receive benefits from a sickness fund. However they need to have paid a contribution for two previous quarters of a year during a waiting period of six months, unless they are exempt. In the waiting period there is no entitlement to sick leave benefits. The daily amount of sickness pay differs substantially between self-employed and salaried workers. For salaried workers this is based on a percentage of their income, for self-employed this is a fixed amount that lowers after time. Compulsory social contributions of salaried workers include unemployment insurance. As for salaried workers, cancer treatments are reimbursed if the contribution during the waiting period is paid.

Finland Social Insurance Institution pays sickness allowance for the salaried and self-employed workers as compensation for loss of income due to incapacity for work lasting less than a full year. According to the legislation (the Self-Employed Persons' (YEL) or Farmers' (MYEL) Pensions Act) the self-employed person needs to take an insurance for old age, disability and death, if self-employment activities have lasted at least four consecutive months. For those insured under the Acts, the sickness allowance and pension is based on the income from work under the YEL or MYEL scheme as confirmed by the pension provider. Sickness allowance may also be available to persons whose self-employment is of limited scope and who are not required to take out YEL or MYEL insurance. All Finnish citizens are entitled to cancer care and treatment within the public health service.

France

Among the self-employed, only craftsmen and shopkeepers received benefits from their specific sickness fund in the period considered by the survey (2010-2012). In contrast, salaried workers were unconditionally compensated by their own fund. Since then, farmers accessed sickness pay in 2014 but liberal professions (self-employed physicians, dentists, pharmacists, architects, lawyers, etc.) remain excluded from sickness benefits, unless they subscribed to a voluntary individual insurance. The daily amount of sickness pay may substantially differ but both self-employed and salaried workers can receive these daily payment allowances for a maximum period of 3 years, equal to half of the mean daily income of the year preceding the work cessation. The compulsory social contributions of salaried workers also include unemployment insurance, disability benefit, retirement allowance and child benefit. The self-employed also access child benefits. Unemployment insurance will be accessible to them soon, but the conditions are not fixed yet. The disability benefits may dramatically depend on the kind of occupation and are usually not enough to compensate for income losses. The amount of the pension is calculated more or less in the same way as for the salaried workers, with slight differences on the pension replacement rates, and may be supplemented by compulsory contributions to one of the specific complementary pension funds (for physicians, dentists, pharmacists, notaries, etc.). Generally speaking, the self-employed, among whom the liberal professions particularly, are strongly encouraged to take out individual provident contracts which provide some tax advantages. As for salaried workers, cancer treatments (inpatient and outpatient care) are fully reimbursed.

Ireland (to earn more than $€ 5,000$ per annum need to make Pay Related Social Insurance (PRSI) payments at a rate of $4 \%$ of their income (to a maximum of $€ 500$ per annum). If these payments are not made, they are only eligible for the reduced rate (non-contributory) old age pension. Generally, the self-employed are not eligible for certain short-term benefits, such as illness benefit (paid to employees unable to work because of ill health) or jobseekers benefit (paid to unemployed people who are capable of, available for, and seeking work). However, if they fulfil specific conditions and meet means-test requirements, self-employed people who become unemployed as a result of their business closing down, have a drop in income, or have an illness or disability may be entitled to certain other payments, such as disability allowance. Those absent from work due to illness may receive sick pay from their employer/business; this is a discretionary (rather than statutory) payment and the level and length of time it is paid varies. All citizens (irrespective of whether or not they are self-employed) are entitled to treatment for cancer in the public sector of the healthcare system; modest co-payments apply unless the individual has a very low income or is unemployed. 
Netherlands

Norway

For self-employed people, there is no entitlement for sick leave benefits in event of illness. The self-employed have to decide whether they wish to take out insurance. All Dutch citizens are entitled to a basic old age pension. Salaried workers receive an additional old-age pension from their former employer(s) pension fund but the self-employed have to decide whether they wish to save money for an additional old-age pension. All Dutch citizens are entitled to treatment for cancer.

For all salaried workers, sick leave is granted from day one and for one year. The sick leave compensation benefit is equivalent to the regular salary or wage, with an upper limit of six times the national insurance basic amount per year (2017: a total of €59137 per year). Therefore, most salaried workers do not have reduced income while on sick leave. After one year of sick leave, the worker is either transferred to disability pension or receives rehabilitation benefits. Income in the form of pension and rehabilitation benefits is less than the original income: approximately $66 \%$ of annual income depending on number of children and income previous years. Self-employed people are granted sick leave compensation from day 17 and for one year, with $66 \%$ of the income on which the sickness benefit is based. Further, for self-employed people, the upper limit of the sickness benefit is six times the national insurance basic amount per year. Self-employed people may buy an insurance policy from the National Insurance Scheme to receive the same sickness benefits as salaried workers. Of the self-employed, $3 \%$ pay for an extra insurance policy to receive the same sickness benefits as salaried. The regulations regarding sick leave, unemployment, rehabilitation benefits and disability pensions are more or less the same for self-employed as for salaried workers. All Norwegian citizens are entitled to cancer care and treatment within the public health service.

UK The National Insurance contributions made by the self-employed are graduated based on level of annual profits; those with low profits may apply for exemption from paying compulsory contributions. Unlike salaried workers, the self-employed cannot get statutory sick pay or contribute to the supplementary state pension. They do, however, qualify for the basic (reduced rate) state pension in the same way as other citizens. Those absent from work due to illness may receive contractual sick pay from their employer/business; this is a discretionary (rather than statutory) payment and the leve and length of time it is paid varies. Self-employed people may be eligible for Employment and Support Allowance (which is for people with an illness, health condition or disability that makes it difficult or impossible to work), if they have paid sufficient National Insurance contributions or meet the meanstest requirements. If they become unemployed, they can claim the same means-tested allowance as other workers, but must be capable of, available for and seeking work. UK residents (irrespective of whether or not they are self-employed and level of National Insurance contributions) are entitled to cancer care within the National Health Service; this is free at the point of delivery. 
Table 3: Description of included datasets

\begin{tabular}{|c|c|c|c|c|c|c|c|c|}
\hline Country & Study ${ }^{1}$ & $\begin{array}{l}\text { Cancer } \\
\text { included }\end{array}$ & $\begin{array}{l}\text { Years of } \\
\text { cancer } \\
\text { diagnosis }\end{array}$ & Time of survey & $\begin{array}{l}\text { No. self-employed/ } \\
\text { salaried individuals }{ }^{2}\end{array}$ & $\begin{array}{l}\text { Mean age at } \\
\text { survey }(\mathrm{SD})^{3}\end{array}$ & $\begin{array}{l}\text { Highest level } \\
\text { of education } \\
\%\end{array}$ & References \\
\hline Belgium & Be1 & Breast & $2008-2009$ & 3 weeks -6 months post-therapy & At survey, $22 \mathrm{SE} ; 362 \mathrm{Sal}$ & ?? & ?? & $\begin{array}{l}\text { Pauwels et al. [19], Van } \\
\text { Hoof et al. [58] }\end{array}$ \\
\hline Finland & Fi1 & $\begin{array}{l}\text { Breast, lymphoma, } \\
\text { testicular, prostate }\end{array}$ & $1997-2001$ & $1-6$ years post-diagnosis & At survey, $54 \mathrm{SE} ; 562 \mathrm{Sal}$ & $\begin{array}{l}\text { SE: } 48(9.5) \\
\text { Sal: } 51(7.8)\end{array}$ & $\begin{array}{l}\text { SE: } 30-28-43 \\
\text { Sal: } 20-22-59\end{array}$ & $\begin{array}{l}\text { Taskila et al. [21], } \\
\text { Hakanen, Lindbohm } \\
\text { [59] }\end{array}$ \\
\hline France & Fr1 & 13 cancer diagnoses & 2010 & 2 years post-diagnosis & $\begin{array}{l}\text { At diagnosis, } 261 \text { SE; } 1871 \text { Sal } \\
\text { At survey, } 232 \text { SE; } 1627 \text { Sal }\end{array}$ & $\begin{array}{l}\text { SE: } 48(6.5) \\
\text { Sal: } 45(7.3)\end{array}$ & $\begin{array}{l}\text { SE: } 5-34-61 \\
\text { Sal: } 9-38-52\end{array}$ & Bouhnik et al. [24] \\
\hline \multirow[t]{4}{*}{ Ireland } & Ir1 & Breast, prostate & $2006-2007$ & $0.5-2$ years post-diagnosis & At diagnosis, $74 \mathrm{SE}, 259 \mathrm{Sal}$ & $\begin{array}{l}\text { SE: } 55(9.0)^{5} \\
\text { Sal: } 50(8.4)^{5}\end{array}$ & $\begin{array}{l}\text { SE: } 12-58-30 \\
\text { Sal: } 11-52-37\end{array}$ & Hanly et al. [60], [15] \\
\hline & Ir2 & Colorectal & $2007-2009$ & $0.5-3$ years post-diagnosis & At diagnosis, $49 \mathrm{SE} ; 135 \mathrm{Sal}$ & $\begin{array}{l}\text { SE: } 64(9.4) \\
\text { Sal: } 56(8.6)\end{array}$ & $\begin{array}{l}\text { SE: } 31-40-29 \\
\text { Sal: } 12-59-29\end{array}$ & Hanly et al. [23] \\
\hline & Ir3 & Head \& Neck & $2006-2011$ & 8 months -6 years post-diagnosis & At diagnosis, $55 \mathrm{SE} ; 101 \mathrm{Sal}$ & $\begin{array}{l}\text { SE: } 57(9.2)^{5} \\
\text { Sal: } 52(10.3)^{5}\end{array}$ & $\begin{array}{l}\text { SE: } 22-47-31 \\
\text { Sal: } 18-50-32\end{array}$ & Pearce et al. [10] \\
\hline & Ir4 & Prostate & $2006-2010$ & $2-6$ years post-diagnosis & At diagnosis, 239 SE; 327 Sal & $\begin{array}{l}\text { SE: } 68(7.8)^{5} \\
\text { Sal: } 64(6.7)^{5}\end{array}$ & $\begin{array}{l}\text { SE: } 33-42-25 \\
\text { Sal: } 21-45-34\end{array}$ & Drummond et al. [22] \\
\hline \multirow[t]{2}{*}{ Netherlands } & $\mathrm{Ne} 1$ & $>8$ cancer diagnoses & $2009-2015$ & 3 months -6 years post-diagnosis & At survey, $44 \mathrm{SE} ; 258 \mathrm{Sal}$ & $\begin{array}{l}\text { SE: } 54(6.9) \\
\text { Sal: } 52(8.1)\end{array}$ & $\begin{array}{l}\text { SE: } 5-50-45 \\
\text { Sal: } 1-50-49\end{array}$ & de Jong [18] \\
\hline & $\mathrm{Ne} 2$ & $>8$ cancer diagnoses & $2009-2015$ & 3 months -6 years post-diagnosis & At survey, $23 \mathrm{SE} ; 107 \mathrm{Sal}$ & $\begin{array}{l}\text { SE: } 54(6.9) \\
\text { Sal: } 52(8.3)\end{array}$ & $\begin{array}{l}\text { SE: } 0-39-61 \\
\text { Sal: } 1-63-36\end{array}$ & de Jong [18] \\
\hline Norway & No1 & 15 cancer diagnoses & $2005-2006$ & $15-39$ months post-diagnosis & $\begin{array}{l}\text { At diagnosis, } 88 \mathrm{SE} ; 1027 \mathrm{Sal} \\
\text { At survey, } 67 \mathrm{SE} ; 881 \mathrm{Sal}\end{array}$ & $\begin{array}{l}\text { SE: } 53(6.9) \\
\text { Sal: } 52(8.4)\end{array}$ & $\begin{array}{l}\text { SE: } 18-43-39 \\
\text { Sal: } 19-30-52\end{array}$ & $\begin{array}{l}\text { Torp et al. [25], Torp et } \\
\text { al. [14] }\end{array}$ \\
\hline UK & UK1 & Prostate & $2006-2010$ & $2-6$ years post-diagnosis & At diagnosis, $108 \mathrm{SE} ; 132 \mathrm{Sal}$ & $\begin{array}{l}\text { SE: } 68(7.5) \\
\text { Sal: } 63(6.0)\end{array}$ & $\begin{array}{l}\text { SE: } 49-19-32 \\
\text { Sal: } 24-33-43\end{array}$ & Drummond et al. [22] \\
\hline
\end{tabular}

${ }^{1}$ All studies have a cross-sectional design

${ }^{2} \mathrm{SE}=$ self-employed, $\mathrm{Sal}=$ salaried

${ }^{3} \mathrm{SD}=$ standard deviation

${ }^{4}$ Primary school - High school - University

${ }^{5}$ Age at time of diagnosis 
Table 4: Work status, sick leave and financial issues in self-employed and salaried cancer survivors who were working at time of diagnosis

\begin{tabular}{|c|c|c|c|c|c|c|c|c|c|c|c|c|c|c|c|c|}
\hline \multirow[t]{2}{*}{ Country } & \multirow[t]{2}{*}{ Study } & \multirow[t]{2}{*}{ Group } & \multicolumn{2}{|c|}{$\begin{array}{l}\text { Working at } \\
\text { survey }\end{array}$} & \multicolumn{2}{|c|}{ Pensioned } & \multicolumn{2}{|c|}{$\begin{array}{l}\text { Occupational } \\
\text { change }\end{array}$} & \multicolumn{2}{|c|}{$\begin{array}{l}\text { Took time off } \\
\text { work due to } \\
\text { cancer }\end{array}$} & \multicolumn{2}{|c|}{$\begin{array}{l}\text { Duration of time } \\
\text { off work } \\
\text { due to cancer }^{1}\end{array}$} & \multicolumn{2}{|c|}{$\begin{array}{l}\text { Financial } \\
\text { compensation } \\
\text { time off work } \\
\end{array}$} & \multicolumn{2}{|c|}{$\begin{array}{l}\text { Negative } \\
\text { financial change } \\
\text { due to cancer }\end{array}$} \\
\hline & & & $\%$ & $p$ & $\%$ & $P$ & $\%$ & $p$ & $\%$ & $p$ & $\begin{array}{l}\text { Mean } \\
\text { months }\end{array}$ & $p$ & $\%$ & $p$ & $\%$ & $p$ \\
\hline Belgium & Be1 & $\begin{array}{l}\text { Self-employed } \\
\text { Salaried }\end{array}$ & $\begin{array}{l}77 \\
40\end{array}$ & 0.09 & - & - & - & - & - & - & - & - & - & - & - & - \\
\hline Finland & Fi1 & $\begin{array}{l}\text { Self-employed } \\
\text { Salaried }\end{array}$ & - & - & - & - & $\begin{array}{l}15^{2} \\
12\end{array}$ & 0.59 & - & - & - & - & - & - & - & - \\
\hline France & Fr1 & $\begin{array}{l}\text { Self-employed } \\
\text { Salaried }\end{array}$ & $\begin{array}{l}89 \\
87\end{array}$ & 0.38 & $\begin{array}{l}2 \\
6\end{array}$ & 0.01 & $\begin{array}{l}7 \\
6\end{array}$ & 0.54 & $\begin{array}{l}62 \\
85\end{array}$ & $<0.001$ & $\begin{array}{l}7.5 \\
6.0\end{array}$ & $<0.001$ & $\begin{array}{l}48^{3} \\
46\end{array}$ & 0.81 & $\begin{array}{l}33 \\
25\end{array}$ & 0.01 \\
\hline Ireland & Ir1 & $\begin{array}{l}\text { Self-employed } \\
\text { Salaried }\end{array}$ & $\begin{array}{l}78 \\
66\end{array}$ & 0.07 & - & - & - & - & $\begin{array}{l}69 \\
88\end{array}$ & $<0.001$ & $\begin{array}{r}9.7 \\
11.3\end{array}$ & 0.57 & $\begin{array}{l}61^{4} \\
65\end{array}$ & $<0.001$ & $\begin{array}{l}65^{5} \\
55\end{array}$ & 0.19 \\
\hline & Ir2 & $\begin{array}{l}\text { Self-employed } \\
\text { Salaried }\end{array}$ & $\begin{array}{l}76 \\
49\end{array}$ & 0.006 & - & - & - & - & $\begin{array}{l}97 \\
89\end{array}$ & 0.20 & $\begin{array}{r}8.6 \\
12.8\end{array}$ & 0.03 & $\begin{array}{l}14^{4} \\
71\end{array}$ & $<0.001$ & - & - \\
\hline & Ir3 & $\begin{array}{l}\text { Self-employed } \\
\text { Salaried }\end{array}$ & $\begin{array}{l}76 \\
57\end{array}$ & 0.05 & - & - & - & - & $\begin{array}{l}86 \\
91\end{array}$ & 0.43 & $\begin{array}{r}5.9 \\
11.6\end{array}$ & 0.02 & $\begin{array}{l}4^{4} \\
57\end{array}$ & $<0.001$ & - & - \\
\hline & Ir4 & $\begin{array}{l}\text { Self-employed } \\
\text { Salaried }\end{array}$ & $\begin{array}{l}86 \\
82\end{array}$ & 0.25 & - & - & - & - & $\begin{array}{l}68 \\
74\end{array}$ & 0.20 & - & - & $\begin{array}{l}13^{4} \\
68\end{array}$ & $<0.001$ & - & - \\
\hline Norway & No1 & $\begin{array}{l}\text { Self-employed } \\
\text { Salaried }\end{array}$ & $\begin{array}{l}76 \\
81\end{array}$ & 0.20 & $\begin{array}{l}9 \\
5\end{array}$ & 0.08 & $\begin{array}{l}51 \\
37\end{array}$ & 0.008 & $\begin{array}{l}86 \\
86\end{array}$ & 0.92 & $\begin{array}{l}61 \%^{6} \\
54 \%\end{array}$ & 0.22 & - & - & $\begin{array}{l}42 \\
24\end{array}$ & 0.001 \\
\hline UK & UK1 & $\begin{array}{l}\text { Self-employed } \\
\text { Salaried }\end{array}$ & $\begin{array}{l}89 \\
86\end{array}$ & 0.50 & - & - & - & - & $\begin{array}{l}50 \\
64\end{array}$ & 0.03 & - & - & $\begin{array}{l}19^{7} \\
81\end{array}$ & $<0.001$ & - & - \\
\hline
\end{tabular}

Dash (-) = not reported. The Dutch studies (Ne1 and Ne2) are omitted because they did not collect data on any of these outcomes

${ }^{1}$ Among those who took time off work due to cancer $\quad{ }^{2}$ Occupational change in the past six years ${ }^{3}$ Only people who were in work at diagnosis and not in work at survey were asked this question $\quad{ }^{4}$ Receipt of sick pay from employer/business; provision of sick pay is discretionary

${ }^{5}$ Participants were asked whether finances affected their work decisions $\quad{ }^{6} \geq 9$ months on sick leave after cancer diagnosis

${ }^{7}$ Receipt of sick pay (statutory, contractual or discretionary) 
Table 5: Working hours in self-employed and salaried cancer survivors working at time of survey

\begin{tabular}{|c|c|c|c|c|c|c|c|c|}
\hline \multirow[t]{2}{*}{ Country } & \multirow[t]{2}{*}{ Study } & \multirow[t]{2}{*}{ Group } & \multicolumn{2}{|c|}{$\begin{array}{l}\text { Mean hours } \\
\text { worked at survey }\end{array}$} & \multicolumn{2}{|c|}{$\begin{array}{l}\text { Reduced } \\
\text { working hours }{ }^{1,2}\end{array}$} & \multicolumn{2}{|c|}{$\begin{array}{l}\text { Mean reduced } \\
\text { working hours }^{3}\end{array}$} \\
\hline & & & Hours/week & $p$ & $\%$ & $p$ & Hours/week & $p$ \\
\hline \multirow[t]{2}{*}{ Belgium } & $\mathrm{Be} 1$ & Self-employed & 20.7 & 0.64 & 31 & 0.40 & 17.2 & 0.91 \\
\hline & & Salaried & 19.9 & & 45 & & 15.2 & \\
\hline \multirow[t]{2}{*}{ France } & Fr1 & Self-employed & 36.1 & 0.97 & 37 & $<0.001$ & 22.4 & 0.001 \\
\hline & & Salaried & 35.9 & & 26 & & 16.7 & \\
\hline \multirow[t]{8}{*}{ Ireland } & Ir1 & Self-employed ${ }^{4}$ & 33.1 & 0.03 & 53 & 0.07 & 17.8 & 0.03 \\
\hline & & Salaried & 28.5 & & 39 & & 12.3 & \\
\hline & Ir2 & Self-employed ${ }^{4}$ & 34.0 & 0.47 & 61 & 0.17 & 29.8 & 0.001 \\
\hline & & Salaried & 31.3 & & 44 & & 13.1 & \\
\hline & Ir3 & Self-employed ${ }^{4}$ & 22.5 & 0.03 & 53 & 0.25 & 24.0 & 0.60 \\
\hline & & Salaried & 17.0 & & 44 & & 25.8 & \\
\hline & Ir4 & Self-employed ${ }^{4}$ & 32.7 & 0.15 & 38 & $<0.001$ & 19.0 & 0.12 \\
\hline & & Salaried & 30.0 & & 19 & & 15.0 & \\
\hline \multirow[t]{4}{*}{ Netherlands } & $\mathrm{Ne} 1$ & Self-employed & 29.6 & 0.92 & - & - & - & - \\
\hline & & Salaried & 28.9 & & - & & - & \\
\hline & $\mathrm{Ne} 2$ & Self-employed & 31.4 & 0.16 & - & - & - & - \\
\hline & & Salaried & 26.7 & & - & & - & \\
\hline \multirow[t]{2}{*}{ Norway } & No1 & Self-employed & 37.3 & 0.51 & 55 & $<0.001$ & 16.4 & 0.28 \\
\hline & & Salaried & 35.7 & & 27 & & 13.8 & \\
\hline \multirow[t]{2}{*}{ UK } & UK1 & Self-employed ${ }^{3}$ & 42.2 & 0.11 & 18 & 0.72 & 16.4 & 0.16 \\
\hline & & Salaried & 38.1 & & 16 & & 12.1 & \\
\hline
\end{tabular}

Dash (-) = not reported. The Finnish study (Fi1) is omitted because it did not collect data on any of these outcomes

${ }^{1}$ Percent of people working after cancer who reduced their working hours at survey compared to at diagnosis

${ }^{2}$ In all countries, salaried workers are either allowed or encouraged by public authorities or health professionals to return to work after sickness for reduced number of hours if needed

${ }^{3}$ Mean reduction in working hours at survey compared to at diagnosis, averaged over those who reported reduced hours

${ }^{4}$ Status at time of diagnosis 
Table 6: Job demands, work ability and quality of life in self-employed and salaried cancer survivors working at time of survey

\begin{tabular}{|c|c|c|c|c|c|c|c|c|c|c|c|c|}
\hline \multirow[t]{2}{*}{ Country } & \multirow[t]{2}{*}{ Study } & \multirow[t]{2}{*}{ Group } & \multicolumn{2}{|c|}{$\begin{array}{l}\text { Physical } \\
\text { demands }\end{array}$} & \multicolumn{2}{|c|}{$\begin{array}{l}\text { Mental } \\
\text { demands }\end{array}$} & \multicolumn{2}{|c|}{ Work ability } & \multicolumn{2}{|c|}{$\begin{array}{l}\text { Work-related } \\
\text { quality of life }\end{array}$} & \multicolumn{2}{|l|}{ Quality of life } \\
\hline & & & $\%$ & $p$ & $\%$ & $p$ & Mean & $\mathrm{p}$ & Mean & $p$ & Mean & $p$ \\
\hline \multirow[t]{2}{*}{ Finland } & $\mathrm{Fi} 1$ & Self-employed $^{1}$ & - & - & - & - & $8.3^{4}$ & 0.96 & - & - & $\begin{array}{r}\text { Physical: } 52.0^{7} \\
\text { Mental: } 46.4^{7}\end{array}$ & $\begin{array}{l}\text { Physical: } 0.61 \\
\text { Mental: } 0.10\end{array}$ \\
\hline & & Salaried & - & & - & & 8.3 & & - & & $\begin{array}{r}\text { Physical: } 51.2 \\
\text { Mental: } 49.0\end{array}$ & \\
\hline \multirow[t]{2}{*}{ France } & Fr1 & Self-employed & $59^{2}$ & 0.01 & $62^{3}$ & 0.47 & - & - & $85 \%^{5}$ & 0.09 & $\begin{array}{c}\text { Physical: } 46.4^{7} \\
\text { Mental: } 44.1^{7}\end{array}$ & $\begin{array}{c}\text { Physical: }<0.001 \\
\text { Mental: } 0.02\end{array}$ \\
\hline & & Salaried & 49 & & 64 & & - & & $89 \%$ & & $\begin{array}{c}\text { Physical: } 43.8 \\
\text { Mental: } 42.4\end{array}$ & \\
\hline \multirow[t]{6}{*}{ Ireland } & $\operatorname{lr} 2$ & Self-employed ${ }^{1}$ & - & - & - & - & - & - & - & - & $71.2^{8}$ & 0.88 \\
\hline & & Salaried & - & & - & & - & & - & & 72.0 & \\
\hline & Ir3 & Self-employed ${ }^{1}$ & - & - & - & - & - & - & - & - & $122.2^{9}$ & 0.88 \\
\hline & & Salaried & - & & - & & - & & - & & 121.6 & \\
\hline & Ir4 & Self-employed ${ }^{1}$ & - & - & - & - & - & - & - & - & $73.5^{8}$ & 0.02 \\
\hline & & Salaried & - & & - & & - & & - & & 78.1 & \\
\hline \multirow[t]{4}{*}{ Netherlands } & $\mathrm{Ne} 1$ & Self-employed & $65^{2}$ & 0.25 & $50^{3}$ & 0.87 & - & - & $78^{6}$ & 0.07 & - & - \\
\hline & & Salaried & 56 & & 52 & & - & & 74 & & - & \\
\hline & $\mathrm{Ne} 2$ & Self-employed & $34^{2}$ & 0.04 & $43^{3}$ & 0.65 & - & - & $75^{6}$ & 0.64 & - & - \\
\hline & & Salaried & 61 & & 49 & & - & & 76 & & - & \\
\hline \multirow[t]{2}{*}{ Norway } & No1 & Self-employed & - & - & - & - & $7.7^{4}$ & 0.03 & - & - & $4.2^{10}$ & 0.76 \\
\hline & & Salaried & - & & - & & 8.3 & & - & & 4.2 & \\
\hline \multirow[t]{2}{*}{ UK } & UK1 & Self-employed ${ }^{1}$ & - & - & - & - & - & & - & - & $83.6^{8}$ & 0.01 \\
\hline & & Salaried & - & & - & & - & & - & & 76.6 & \\
\hline
\end{tabular}

Dash (-) = not reported. The Belgian (Be1) study and an Irish (Ir1) study are omitted because they did not collect data on any of these outcomes

1Status at time of diagnosis 2Single question: "Would you say that your job is physically demanding?" (response alternatives "no" and "yes")

${ }^{3}$ Single question: "Would you say that your job is mentally demanding?" (response alternatives "no" and "yes")

${ }^{4}$ Single question from Work Ability Index, mean of current work ability compared with lifetime best (score range $0-10$, higher score $=$ better work ability)

5Single question: "Overall, are you satisfied with your job?" (response alternatives "no" and "yes")

${ }^{6}$ Measured using the Quality of Working Life Questionnaire for Cancer survivors (QWLQ-CS) (score range 0-100; higher score = better quality of working life)

${ }^{7}$ Short Form-12 questionnaire on health related quality of life (score range $0-100$; higher score = better quality of life)

${ }^{8}$ EORTC-QLQ30 global health score (score range $0-100$; higher score $=$ better quality of life)

${ }^{9} \mathrm{FACT}-\mathrm{G}$ plus FACT-HN (score range 0 - 156; higher score = better quality of life)

${ }^{10}$ Single question: "Overall, how do you think you are doing?" (five-point response scale from very poor to very good) 